\title{
Effect of Urea Treatment of Roughages and in vitro Digestibility of Available Feed Resources in Maradi Area of Niger
}

\author{
Nourou Abdou ${ }^{1,}$, , Nasreldin Basha ${ }^{2}$, Abdoulaye Soumana Gouro ${ }^{3}$, Ignatius Verla Nsahlai ${ }^{4}$ \\ ${ }^{1}$ Department of Animal Production, National Institute for Agricultural Research, Niamey, Niger \\ ${ }^{2}$ Faculty of Agriculture and Veterinary Medecine, Qassim University, Al-Qassim, Saudi Arabia \\ ${ }^{3}$ Department of Animal Production, Faculty of Agronomy, University Abdou Moumouni, Niamey, Niger \\ ${ }^{4}$ Department of Animal and Poultry Science, University of KwaZulu-Natal, Pietermaritzburg, South Africa
}

Email address:

nourouabdu@yahoo.fr (N. Abdou)

${ }^{*}$ Corresponding author

\section{To cite this article:}

Nourou Abdou, Nasreldin Basha, Abdoulaye Soumana Gouro, Ignatius Verla Nsahlai. Effect of Urea Treatment of Roughages and in vitro Digestibility of Available Feed Resources in Maradi Area of Niger. American Journal of Agriculture and Forestry.

Vol. 6, No. 4, 2018, pp. 78-83. doi: 10.11648/j.ajaf.20180604.13

Received: July 7, 2018; Accepted: July 17, 2018; Published: August 17, 2018

\begin{abstract}
The effect of urea treatment of roughages and the digestibility of feeds for ruminants was studied in southern Niger. Cereal straws, legume crop residues and concentrates were collected in the dry season. Cereal straws were millet stover, sorghum stover with its fractions (leaves and sheath, stems), Diheteropogon hagerupii, Eragrostis tremula and Schizachyrium exile and legume crop residues were groundnut haulms and cowpea husk. Cereal straws and cowpea husk were either untreated or treated with urea. In vitro digestibility characteristics were determined using rumen fluid from fistulated Jersey cows and metabolizable energy (ME) was determined through gas production after $24 \mathrm{~h}$ of incubation. Cereal straws had different $(\mathrm{P}<0.001)$ apparent degradability (Apdeg), degradation rate $(C)$, halflife to the maximum gas volume $\left(\mathrm{T}_{1 / 2}\right)$, degradation efficiency factor (DEF) and ME. Whereas, urea treated cereal straws had higher $(\mathrm{P}<0.001)(\mathrm{C})$ and increased $(\mathrm{P}<0.01)$ ME. Legume crop residues did not affect $(\mathrm{P}>0.05)$ in vitro parameters, however, treating cowpea husk decreased $(\mathrm{P}<0.05)$ gas production and $\left(\mathrm{T}_{1 / 2}\right)$ but increased ME $(\mathrm{p}<0.01)$. Concentrate degradation and kinetics parameters varied $(\mathrm{P}<0.001)$ strongly, while Apdeg and true degradability varied $(\mathrm{P}<0.01)$ leaving microbial yield $(\mathrm{MY})$ unaffected. These findings will contribute to better utilization of the concerned feed resources by ruminants in Niger and related environment.
\end{abstract}

Keywords: Cereal Straws, Concentrates, Digestibility, Gas Production, Legume Crop Residues, Urea Treatment

\section{Introduction}

Nutritive value of feed is determined by its chemical composition and digestibility [1]. In Niger, high quality feeds are only available during the rainy season which lasts for four months per annum, whereas during the dry season feeds are scarce and have low nutritive value. Consequently, ruminant animals largely depend on cereal straws which are low in protein and available energy $[2,3]$. Chemical treatment and/or supplementation with protein sources were used to improve the quality of these straws $[2,4]$ However, research for development projects have accorded more attention on urea treatment due to its advantage of improving intake, digestibility and nitrogen content and reducing the use of concentrate $[2,4]$.

The tendency these days is the use of agro-industrial by-products and crop residues for feeding ruminants in Niger [5] without due regard for nutritive values in West African countries. To evaluate nutritional attributes of these feed resources, in vitro degradability was used. In vitro digestibility has been widely used to assess the nutritional quality of feeds [6]. In the current study, cereal straws were treated with urea 
in order to assess the effect of urea treatment on in vitro digestibility parameters. The objective of this study was to determine the effect of urea treatment on predominant roughages and to evaluate the quality of some feeds available in Southern Niger using in vitro digestibility techniques in order to contribute to better utilization of feed resources by ruminants in Niger.

\section{Materials and Methods}

\subsection{Feeds}

Feeds were brought from Maradi, South of Niger, with an annual rain fall of 350-600 mm; and a composite sample taken for urea treatment and laboratory analyses. Feeds were grouped into three classes: (1) cereal straws: millet stover (Pennisetum typhoides), sorghum (Sorghum bicolor) stover (whole sorghum stover, SS; sheath and leaves, SSL; stems, SSS), Eragrostis tremula, Schizachyrium exile and Diheteropogon hagerupii; (2) legume crop residues: groundnut (Arachis hypogea) haulms and cowpea (Vigna unguiculata) husk; and (3) concentrates: millet bran, wheat bran and cottonseed cake. All roughages (without SSL, SSS and groundnut haulms) were sprayed with $3 \%$ urea solution at $50 \% \mathrm{w} / \mathrm{w}$ of straw mixed and stored in plastic bags for 40 days Concentrates used in this study are available to smallholder farmers in Southern Niger.

\subsection{Gas Production}

Two donors Jersey cows $(\sim 350 \mathrm{~kg}$ live weight $)$ fitted with a rumen cannula were kept under natural grazing of kikuyu (Pennisetum clandestinum) pasture. These two cows had access to $2 \mathrm{~kg}$ of Lucerne per cow day in the afternoon, besides a mineral lick ad libitum. All roughages (treated with urea and untreated) and concentrates were used to determine gas production following the automated gas production technique [7]. Ingredients were ground (1 mm screen) and a total of $1.0 \pm 0.0010 \mathrm{~g} \mathrm{DM}$ of each sample was weighed into a $250 \mathrm{ml}$ Duran bottle for in vitro incubation. Roughages and concentrates were incubated separately. During each run, there were three controls of Lucerne (alfalfa - Medicago sativa) and three blanks (only rumen fluid and buffer). Roughages were incubated in 4 runs in a completely randomised block design. Concentrates were incubated in 3 runs in a completely randomised design with 5 replicates per sample. A salivary buffer solution was prepared [8]. A $67 \mathrm{ml}$ solution of the buffer was added to each sample and to each blank bottle. These bottles were kept in the incubator $\left(39^{\circ} \mathrm{C}\right)$ for $1 \mathrm{hr}$ to allow soaking of substrate prior incubation. Meanwhile, a mixture of rumen fluid was collected prior to morning feeding, squeezed and filtered through four layers of cheesecloth into a pre-warmed flask container $\left(39^{\circ} \mathrm{C}\right)$ that had been flushed with carbon dioxide $\left(\mathrm{CO}_{2}\right)$ and transported to the laboratory. Inoculation was completed by adding $33 \mathrm{ml}$ of the rumen fluid into each bottle under a stream of $\mathrm{CO}_{2}$ and tightening bottle lids. Duran bottles were incubated and channels of pressure sensors were fitted. Pressure was logged at 20 min interval during a 72-hours and 48-hours incubation period for roughages and concentrates, respectively, and was converted to volume using a predetermined calibration equation. The metabolizable energy value was calculated according to [9] as follows: $\mathrm{ME}(\mathrm{MJ} / \mathrm{kg} \mathrm{DM})=2.20+0.136 \mathrm{G}_{24}+0.057 \mathrm{CP}+$ $0.0029 \mathrm{CP}^{2}$; Where $\mathrm{CP}=$ crude protein in $\mathrm{g}$ per $100 \mathrm{~g} \mathrm{DM}$, and $\mathrm{G}_{24}$ is the gas volume at $24 \mathrm{~h}$ after incubation (ml) of $200 \mathrm{mg}$. In this study gas volume after 24 hours was converted from $1000 \mathrm{mg}$ to $200 \mathrm{mg}$ of material incubated.

\subsection{In vitro Digestibility}

After 72-hours and 48-hours incubation period for roughages and concentrates, respectively as described above, the $\mathrm{pH}$ was measured and samples were centrifuged at $17,700 \mathrm{xg}$ for 20 minutes at $4^{\circ} \mathrm{C}$. Then the supernatant was poured out, the residue transferred into a container (with known weight) and placed in the oven $\left(70^{\circ} \mathrm{C}\right)$ for 5-6 days until dried constancy. Dry residues were corrected for blank incubation which contained only buffer and rumen fluid. The difference in mass between the dry residue and the mass of the incubated material represented apparent degradability (Apdeg). The residue was refluxed with neutral detergent solution (NDF) using ANKOM-A200/2220 (Macedon, NY, USA). www.ankom.com). The resulting weight of NDF (after correction) was subtracted from the mass of the incubated material which represented the true degradability (Trdeg) [10, 11]. The difference between Trdeg and Apdeg represented the microbial yield (MY) $[12,11]$.

The experimental design was a completely randomised block design ( 9 feeds $x 4$ runs) for roughages in Experiment 1 and ( 3 feeds x 5 pseudo replications x 5 runs) for concentrates in experiment 2 . The model described by [13] was fitted to gas volumes to determine gas production kinetics following a two steps process:

$$
\mathrm{Y}=\mathrm{GP} /(1+\mathrm{e}(2+4 \mathrm{C}(\mathrm{Lt}-\mathrm{t}))[14]
$$

Where $\mathrm{Y}$ is the total gas volume $(\mathrm{mL})$ at time $\mathrm{t}$, GP is the maximum gas production, $\mathrm{C}$ is the overall rate of gas production, and $\mathrm{Lt}$ is the bacteria colonization or Lag time (h). The cumulative gas production (GP) was used to calculate the maximum rate of GP at the point of inflection $(\mu)$ and the time taken to produce half of the gas volume ( $\left.\mathrm{T}^{1 / 2}\right)$ according to [15] as follows:

$$
\begin{aligned}
& \mu(\mathrm{ml} / \mathrm{h})=\mathrm{GP} \times \mathrm{C} \text { and } \\
& \mathrm{T}_{1 / 2}(\mathrm{~h})=\mathrm{Lt}+1 /(2 * \mathrm{C})
\end{aligned}
$$

The partitioning factor $(\mathrm{PF})[16,17]$ and the degradation efficiency factor (DEF) [18] were calculated as follows:

$$
\begin{gathered}
\mathrm{PF}=\text { Trdeg/GP } \\
\mathrm{DEF}=\text { Trdeg } / \mathrm{T}_{1 / 2} \times \mathrm{GP}_{1 / 2}=2 \mathrm{PF} / \mathrm{T}_{1 / 2}
\end{gathered}
$$

\subsection{Statistical Analyses}

Data were subjected to the General Liner Model of SAS to determine the effects of feeds, urea treatment and interaction 
feed versus urea treatment on gas production parameters, the statistical significance being declared at $\mathrm{P}<0.05$. Means were compared by least squares means (LSMEANS). The models used were:

$$
\mathrm{Y}_{\mathrm{ijkl}}=\mu+\mathrm{f}_{\mathrm{i}}+\mathrm{u}_{\mathrm{j}}+(\mathrm{fu})_{\mathrm{ij}}+\operatorname{run}_{\mathrm{k}}+\mathrm{e}_{\mathrm{ijkl}}(\text { Experiment } 1) ;
$$

Where, $\mathrm{Y}_{\mathrm{ijk}}$ is the independent variable (GP parameters, in vitro degradability), $\mu$ is the overall mean, fi is the effect of feed roughages $(i=1-9), u_{j}$ is the urea treatment effect $(j=1)$, $(\mathrm{fu})_{\mathrm{ij}}$ is the interaction between feeds and urea treatment, runk is the effect of run $(\mathrm{k}=1-4)$ and $\mathrm{e}_{\mathrm{ijk} \mathrm{l}}$ the residual error.

$$
\mathrm{Y}_{\mathrm{ijkl}}=\mu+\mathrm{f}_{\mathrm{i}}+\mathrm{rj}+\operatorname{run}_{\mathrm{k}}+\mathrm{e}_{\mathrm{ijkl}}(\text { Experiment2); }
$$

Where, $\mathrm{Y}_{\mathrm{ijk}}$ is the independent variable (GP parameters), $\mu$ is the overall mean, $f i$ is the effect of feed concentrates $(3$ feeds $x 5$ pseudo replications) ( $\mathrm{i}=1-3)$, rj is the effect of replication $(j=1-5)$, runj is the effect of run $(j=1-5)$ and $e_{i j k l}$ the residuel error.

\section{Results}

\subsection{Dry Matter Degradability and Gas Production}

The three classes of feeds had different $(\mathrm{P}<0.001)$ apparent degradability (Apded), true degradability (Trdeg), microbial yield (MY), rate of gas production $(\mathrm{C})$, and maximum gas production (GP) but had no effect $(\mathrm{P}>0.05)$ on $\mathrm{pH}$ (Table 1$)$. These classes had different $(\mathrm{P}<0.001)$ metabolisable energy (ME).

Within cereal straws, feed types affected Apdeg $(\mathrm{P}<0.001)$, C $(\mathrm{P}<0.001)$, Trdeg $(\mathrm{P}<0.01)$, MY $(\mathrm{P}<0.001)$ and GP $(\mathrm{P}<0.001)$. Urea treatment increased Trdeg $(\mathrm{P}<0.01), \mathrm{MY}$ $(\mathrm{P}<0.05)$ and $(\mathrm{C})(\mathrm{P}<0.001)$. GP was highest in Eragrotis and lowest in millet stover and was affected by cereal type $(\mathrm{P}<0.01)$. Cereal straws had different $(\mathrm{P}<0.001) \mathrm{ME}$ where fraction of sorghum stover leaves \& sheath (SSL) and stems (SSS) had the highest ME and Diheteropogon and millet stover the lowest $(\mathrm{P}<0.001)$. Treating cereal straws increased $(\mathrm{P}<0.01)$ the $\mathrm{ME}$ content, with no indication of any interaction.

There was no effect ( $p>0.05)$ of legume crop residues on all gas production parameters and ME. However, treating cowpea husk increased $\mathrm{pH}(\mathrm{P}<0.05)$ and $\mathrm{ME}(\mathrm{P}<0.01)$ but decreased $(\mathrm{P}<0.05)$ the GP.

Concentrates affected $(\mathrm{P}<0.01)$ Apdeg, Trdeg, highly affected $(\mathrm{P}<0.001) \mathrm{pH}$, maximum gas production $(\mathrm{GP})$, gas production rate $(\mathrm{C})$ and $\mathrm{ME}$. However, MY was similar $(\mathrm{P}>0.05)$ among concentrates. The TrDeg in wheat bran was higher $(\mathrm{P}<0.01)$ than in millet bran and cottonseed cake. The same trend $(\mathrm{P}<0.001)$ was observed with GP.

\begin{tabular}{|c|c|c|c|c|c|c|c|c|}
\hline Feeds & UT & Apdeg & TrDeg & MY & pH & GP & $\mathbf{C}$ & ME (MJ/kg DM) \\
\hline \multicolumn{9}{|l|}{ Cereal straws class } \\
\hline \multirow[t]{2}{*}{ Diheteropogon hagerupii } & - & 377 & 623 & 246 & 6.83 & 128 & 0.021 & 3.61 \\
\hline & + & 418 & 592 & 174 & 6.70 & 125 & 0.024 & 3.65 \\
\hline \multirow[t]{2}{*}{ Eragrostis tremula } & - & 461 & 580 & 119 & 6.67 & 137 & 0.021 & 4.18 \\
\hline & + & 480 & 626 & 146 & 6.71 & 128 & 0.023 & 4.23 \\
\hline \multirow[t]{2}{*}{ Schyzachiryum exile } & - & 410 & 629 & 218 & 6.69 & 122 & 0.024 & 4.00 \\
\hline & + & 366 & 682 & 317 & 6.77 & 129 & 0.027 & 4.12 \\
\hline \multirow[t]{2}{*}{ Millet stover } & - & 382 & 550 & 169 & 6.78 & 82 & 0.026 & 3.55 \\
\hline & + & 375 & 676 & 301 & 6.91 & 103 & 0.025 & 3.86 \\
\hline \multirow[t]{2}{*}{ Sorghum stover (SS) } & - & 532 & 631 & 99 & 6.77 & 121 & 0.020 & 4.09 \\
\hline & + & 462 & 684 & 222 & 6.71 & 120 & 0.022 & 4.21 \\
\hline SS leaves sheath & - & 597 & 699 & 102 & 6.67 & 128 & 0.027 & 5.17 \\
\hline SS stems & - & 508 & 579 & 71 & 6.70 & 140 & 0.019 & 4.53 \\
\hline \multicolumn{9}{|l|}{ Legume crop residues class } \\
\hline \multirow[t]{2}{*}{ Cowpea husks } & - & 505 & 703 & 198 & 6.68 & 156 & 0.045 & 6.62 \\
\hline & + & 553 & 671 & 118 & 6.75 & 144 & 0.049 & 6.97 \\
\hline \multicolumn{9}{|l|}{ Concentrates class } \\
\hline Cottonseed cake & - & 349 & 730 & 450 & 6.83 & 116 & 0.018 & 6.29 \\
\hline Millet bran & - & 469 & 855 & 430 & 6.66 & 156 & 0.063 & 7.58 \\
\hline Wheat bran & - & 438 & 873 & 505 & 6.64 & 180 & 0.073 & 8.49 \\
\hline \multicolumn{9}{|l|}{ Variation sources } \\
\hline \multicolumn{9}{|l|}{ Between classes } \\
\hline RMSE & & 87.58 & 79.87 & 115.14 & 0.11 & 21.044 & 0.014 & 0.69 \\
\hline \multicolumn{9}{|l|}{ Within cereal straws } \\
\hline RMSE & & 40.28 & 53.03 & 72.42 & 0.10 & 11.61 & 0.0007 & 0.13 \\
\hline Feed effect & & $* * *$ & $* *$ & $* *$ & NS & $* *$ & $* * *$ & $* * *$ \\
\hline Treatment effect & & NS & $* *$ & $*$ & NS & NS & $* * *$ & $* *$ \\
\hline Feed*treatment & & NS & NS & $*$ & NS & NS & $* *$ & NS \\
\hline \multicolumn{9}{|l|}{ Within legume crop residues } \\
\hline RMSE & & 79.17 & 44.23 & 117.98 & 0.02 & 4.65 & 0.002 & 0.12 \\
\hline Feed effect & & NS & NS & NS & NS & NS & NS & NS \\
\hline Treatment effect & & NS & NS & NS & $*$ & $*$ & NS & $* *$ \\
\hline Within concentrates & & & & & & & & \\
\hline
\end{tabular}

Table 1. Degradability and gas production factors of feeds using in vitro digestibility. 


\begin{tabular}{lllllllll}
\hline Feeds & UT & Apdeg & TrDeg & MY & pH & GP & C & ME (MJ/kg DM) \\
\hline RMSE & & 61.87 & 46.07 & 152.5 & 0.05 & 15.53 & 0.007 & 0.23 \\
Feed effect & & $* *$ & $* *$ & NS & $* * *$ & $* * *$ & $* * *$ & $* * *$ \\
\hline
\end{tabular}

UT: urea treatment; Apdeg: the apparent degradability ( $\left.\mathrm{mg} \mathrm{g}^{-1} \mathrm{DM}\right)$; Trdeg: true degradability ( $\left.\mathrm{mg} \mathrm{g}^{-1} \mathrm{DM}\right)$; MY: microbial yield (mg g $\left.{ }^{-1} \mathrm{DM}\right)$; GP: maximum gas production $\left(\mathrm{ml} \mathrm{g}^{-1} \mathrm{DM}\right) ; \mathrm{C}$ : constant degradation rate of gas production $\left(\mathrm{h}^{-1}\right)$; ME: metabolizable energy; RMSE: Root mean square error; NS $(\mathrm{P}>0.05) ;{ }^{*}(\mathrm{P}<$ $0.05) ; * *(\mathrm{P}<0.01) ; * * *(\mathrm{P}<0.001)$.

\subsection{Derived Factors of GP of Feeds}

The three classes of feeds strongly $(\mathrm{P}<0.001)$ affected halflife to the maximum gas volume $\left(\mathrm{T}_{1 / 2}\right)$, maximum rate of gas production at the point of inflection of the gas curve $(\mu)$ and degradation efficiency factor (DEF). They slightly $(\mathrm{P}<0.05)$ affected the partitioning factor $(\mathrm{PF})$ (Table 2).

Within cereal straws, feed type affected $(\mathrm{P}<0.001)$ halflife to the maximum gas volume $\left(\mathrm{T}_{1 / 2}\right)$, maximum rate of gas production at the point of inflection of the gas curve $(\mu)$, the partitioning factor (PF) and degradation efficiency factor (DEF). Among cereal straws, Diheteropogon ( $34.9 \mathrm{~h}$ and 0.29 ) had the highest $(\mathrm{P}<0.001) \mathrm{T}_{1 / 2}$ and lowest $\mathrm{DEF}$, respectively, whereas SSL $(22.4 \mathrm{~h}$ and $4.14 \mathrm{ml} / \mathrm{h})$ had the lowest $T_{1 / 2}$ and highest $(\mathrm{P}<0.001)(\mu)$, respectively. Millet stover had the lowest $\mu(2.22 \mathrm{ml} / \mathrm{h})$ and highest PF (6.58), whereas SSL (0.46) had the highest DEF and SSS (0.46) had the lowest PF. However, urea treatment increased $(p<0.05)(\mu)$ but did not affect any other factor. All these factors were not affected $(\mathrm{P}>0.05)$ by legume crop residues. Treatment of cowpea husk with urea increased $\left(\mathrm{T}_{1 / 2}\right)$ but did not affect any other factor.

Concentrates highly $(\mathrm{P}<0.001)$ affected halflife to the maximum gas volume $\left(\mathrm{T}_{1 / 2}\right)$, maximum rate of gas production at the point of inflection of the gas curve $(\mu)$ and degradation efficiency factor $(\mathrm{DEF})$. They had different $(\mathrm{P}<0.01)$ on partitioning factor $(\mathrm{PF})$. Wheat bran had the highest $(\mathrm{P}<0.001)$ $(\mu)$ and $\mathrm{DEF}$, and the lowest $(\mathrm{P}<0.001)\left(\mathrm{T}_{1 / 2}\right)$. Inversely, cottonseed cake had the highest $(\mathrm{P}<0.001)\left(\mathrm{T}_{1 / 2}\right)$ and $(\mathrm{PF})$, and the lowest $(\mathrm{P}<0.001)(\mu)$.

Table 2. Gas production and kinetic factors of feeds using in vitro digestibility.

\begin{tabular}{|c|c|c|c|c|c|}
\hline Feeds & UT & $T_{1 / 2}$ & $\mu$ & $\mathbf{P F}$ & DEF \\
\hline \multicolumn{6}{|l|}{ Cereal straws class } \\
\hline \multirow[t]{2}{*}{ Diheteropogon hagerupii } & - & 34.9 & 2.77 & 4.97 & 0.29 \\
\hline & + & 35.6 & 3.03 & 4.76 & 0.28 \\
\hline \multirow[t]{2}{*}{ Eragrostis tremula } & - & 29.3 & 2.95 & 4.46 & 0.30 \\
\hline & + & 30.0 & 2.95 & 4.88 & 0.33 \\
\hline \multirow[t]{2}{*}{ Schizachyrium exile } & - & 28.8 & 2.97 & 4.94 & 0.33 \\
\hline & + & 29.8 & 3.49 & 5.30 & 0.35 \\
\hline \multirow[t]{2}{*}{ Millet stover } & - & 26.0 & 2.22 & 5.75 & 0.42 \\
\hline & + & 28.2 & 2.59 & 6.58 & 0.47 \\
\hline \multirow[t]{2}{*}{ Sorghum stover (SS) } & - & 29.6 & 2.47 & 5.26 & 0.36 \\
\hline & + & 28.7 & 2.70 & 5.72 & 0.40 \\
\hline SS leaves sheath & - & 22.4 & 4.14 & 5.44 & 0.46 \\
\hline SS stems & - & 31.0 & 2.51 & 4.19 & 0.29 \\
\hline \multicolumn{6}{|l|}{ Legume crop residues class } \\
\hline \multirow[t]{2}{*}{ Cowpea husks } & - & 13.8 & 7.09 & 4.75 & 0.65 \\
\hline & + & 15.1 & 7.15 & 4.64 & 0.62 \\
\hline Groundnut haulms & - & 14.5 & 6.43 & 5.01 & 0.69 \\
\hline \multicolumn{6}{|l|}{ Concentrates class } \\
\hline Cottonseed cake & - & 31.4 & 2.05 & 6.3 & 0.40 \\
\hline Millet bran & - & 12.4 & 9.83 & 5.5 & 0.88 \\
\hline Wheat bran & - & 9.5 & 13.12 & 4.8 & 1.02 \\
\hline \multicolumn{6}{|l|}{ Variation sources } \\
\hline \multicolumn{6}{|l|}{ Between classes } \\
\hline Root MSE & & 5.92 & 2.74 & 0.65 & 0.17 \\
\hline Class effect & & $* * *$ & $* * *$ & $*$ & $* * *$ \\
\hline \multicolumn{6}{|l|}{ Within cereal straws } \\
\hline RMSE & & 1.30 & 0.34 & 0.59 & 0.04 \\
\hline Feed effect & & $* * *$ & $* * *$ & $* * *$ & $* * *$ \\
\hline Treatment effect & & NS & $*$ & NS & NS \\
\hline Feed*treatment & & NS & NS & NS & NS \\
\hline \multicolumn{6}{|c|}{ Within legumes crop residues } \\
\hline RMSE & & 0.39 & 0.38 & 0.42 & 0.06 \\
\hline Feed effect & & NS & NS & NS & NS \\
\hline Treatment effect & & $*$ & NS & NS & NS \\
\hline \multicolumn{6}{|l|}{ Within concentrates } \\
\hline RMSE & & 2.73 & 1.13 & 1.17 & 0.21 \\
\hline Feed effect & & $* * *$ & $* * *$ & $* *$ & $* * *$ \\
\hline
\end{tabular}

UT: urea treatment; $\mathrm{T}_{1 / 2}$ : halflife to the maximum gas volume $(\mathrm{h}) ; \mu$ : maximum rate of gas production at the point of inflection of the gas curve $(\mathrm{ml} / \mathrm{h}), \mathrm{PF}$ : partitioning factor; DEF: degradation efficiency factor; RMSE: Root mean square error; NS ( $\mathrm{P}>0.05)$; ${ }^{*}(\mathrm{P}<0.05)$; ** $(\mathrm{P}<0.01) ;{ }^{* * *}(\mathrm{P}<0.001)$. 


\section{Discussion}

Treating with urea generates gaseous ammonia and carbonic gas, which spread and treat forages and ensure good conservation and quality $[4,3]$. This ensures the breakdown of chemical bonds between lignin, hemicellulose and cellulose, which are respectively indigestible, partially digestible or completely digestible.

Cereal straws, legume crop residues and concentrates had high effect on in vitro digestibility due to differences in physical and chemical composition in agreement with others $[19,20,3]$. The facts that urea treatment increased Trdeg, MY and (C) except with Diheteropogon and cowpea husk confirms an increase in quality and in rumen microbial activity and cell wall digestion of the feeds [20]. Gas production was highest in Eragrostis and lowest in millet stover and conversely millet stover had higher MY than Eragrostis. These results agree with [21] stipulating that GP and microbial yield are inversely related. Differences in ME among cereal straws can be attributed to differences in chemical composition of feeds.

The increase of ME of urea-treated cowpea husk could be due to increased nitrogen content [3] and probably ether extract. It was shown an improvement of nutritive value of moistened cowpea husk through increased microbial yield, nitrogen content and ether extract [18]. However, overflow of ammonia causes protein wastage when fermentable energy is insufficient to support microbial growth required to utilise the excess degraded protein [22], however reasons need to be sorted to explain why urea-treatment of cowpea husk decreased feed digestion and GP. Additionally, microbial fermentation in the rumen is highly dependent on the protein: energy $(\mathrm{P} / \mathrm{E})$ ratio $[23]$.

Wheat bran had higher Trdeg and GP than millet bran in agreement a study [24] stipulating that nitrogen content is positively correlated to degradation parameters. The low Trdeg and GP of cottonseed cake compared to brans despite its high nitrogen content may be due to the presence of gossypol (phenolic organic compound) which could inhibit microbial activity in the rumen [25]. These findings were also supported by [26] who reported that free gossypol decreased crude protein content and in vitro digestibility. Furthermore, that condensed tannin constituted a limiting factor of in vitro gas production [27].

The large variation of kinetic factors, half time $\left(T_{1 / 2}\right)$, maximum rate of GP $(\mu), \mathrm{PF}$ and DEF within cereal straws is in agreement with [28]. Values of $\mathrm{T}_{1 / 2}$ and DEF in maize stover and grass hay reported by [18] were lower and overlapped our findings on cereal straws. It may be conclude that our cereal straws are lower in nutritive values [3] than these grass hay and maize stover. That urea treatment increased $(\mu)$ for all straws may be explained by increased rate of degradation (C) due to increased rumen microbial activity and cell wall digestion [29]. It is possible that urea-treatment of cowpea husk may increase $T_{1 / 2}$ because ammonia interact with lignin producing phenolic compound that inhibit bacteria growth.

The kinetic factors were significantly affected by concentrates due to differences in chemical composition among concentrates $[30,3]$. Wheat bran with low NDF and high nitrogen content $[2,3]$ had higher $(\mu)$ and (DEF) and lower $\left(\mathrm{T}_{1 / 2}\right)$ than millet bran. The highest $\left(T_{1 / 2}\right)$ and lowest $(\mu)$ and (DEF) observed in cottonseed cake may be due to its content of gossypol which decreased its degradability [25]. Additionally, feeds with high Trdeg, C, $\mu$, DEF and low $\mathrm{T}_{1 / 2}$ and Lt may predict good nutritive value and good microbial efficiency in agreement with $[31,18]$. It should be stated that urea-treatment of cowpea husk emitted an objectionable odour which is yet unquantified. This suggests that either energy or nitrogen is unavailable for use or bacteria-inhibitory factor occur in urea-treated cowpea husk. Since, cowpea husk by itself constitutes a good source of protein and energy it should not be urea-treated.

\section{Conclusion}

Cereal straws are low in $\mathrm{ME}$ and in vitro digestion while legume crop residues and concentrates are high in ME and in vitro digestion parameters. Urea treatment did not conclusively increase the in vitro digestion and $\mathrm{ME}$ content of cereal straws as expected. To increase the feeding values of tropical cereal straws with low nutritive value, urea-treated straws supplemented with concentrates and legume crop residues are good strategies to curb the consequence of long dry season in this area.

\section{Conflict of Interest}

This manuscript is our own research with the original data. We acknowledge that all authors have contributed significantly; so there is no conflict of interest.

\section{Acknowledgements}

The authors acknowledge the funding provided by the West Africa Agricultural Productivity Programme (WAAPP/PPAAO) of Niger (grant number: 4877-NE). Partial funding for laboratory analysis was obtained from P029 UKZN research code. The authors wish to express their gratitude to the Discipline of Animal and Poultry Sciences, SAEES, UKZN, Rep. South Africa for providing materials and equipment of their laboratory. We also thank the staff of Ukulinga Research Farm of the University of KwaZulu-Natal for helping with their donor Jersey cows.

\section{References}

[1] Belachew, Z., Yisehak, K., Taye, T., Janssens, G., 2013. Chemical composition and in sacco ruminal degradation of tropical trees rich in condensed tannins. Czechoslovakia Journal of Animal Science 58, 176-192.

[2] Abdou, N., Nsahlai, I., Chimonyo, M., 2011. Effects of groundnut haulms supplementation on millet stover intake, digestibility and growth performance of lambs. Animal Feed Science and Technology 169, 176-184. 
[3] Abdou N., Gouro A. S, Nsahlai I. V., 2017. Nutritional Characteristics of Available Feed Resources in Maradi Area of Niger. Animal Nutrition and Feed Technology. 17, 229-243.

[4] Kashongwe, B., Bebe, B., Ooro, P., Migwi, P., Onyango, T., 2017. Integrating Characterization of Smallholders' Feeding Practices with On-Farm Feeding Trials to Improve Utilization of Crop Residues on Smallholder Farms. Advances in Agriculture 2017.

[5] Ali, L., Van den Bossche, P., Thys, E., 2003. Enjeux et contraintes de l'élevage urbain et périurbain des petits ruminants à Maradi au Niger: quel avenir ? Revue d'élevage et de médecine vétérinaire des pays tropicaux 56 (1-2).

[6] Arbabi, S., Ghoorchi, T., Ramzanpour, S., 2017. Use of an in vitro Rumen Gas Production Technique to Evaluate the Nutritive Value of Five Forage to Concentrate Ratios. Iranian Journal of Applied Animal Science 7.

[7] Pell, A., Schofield, P., 1993. Computerized monitoring of gas production to measure forage digestion in vitro. Journal of Dairy Science 76, 1063-1073.

[8] McDougall, E., 1948. Studies on ruminant saliva. 1. The composition and output of sheep's saliva. Biochemical Journal $43,99$.

[9] Menke, K., Raab, L., Salewski, A., Steingass, H., Fritz, D., Schneider, W., 1979. The estimation of the digestibility and metabolizable energy content of ruminant feedingstuffs from the gas production when they are incubated with rumen liquor in vitro. The Journal of Agricultural Science 93, 217-222.

[10] Van Soest, P. v., Robertson, J., Lewis, B., 1991. Methods for dietary fiber, neutral detergent fiber, and nonstarch polysaccharides in relation to animal nutrition. Journal of dairy science 74, 3583-3597.

[11] Blümmel, M., Steingaß, H., Becker, K., 1997b. The relationship between in vitro gas production, in vitro microbial biomass yield and $\mathrm{N}$ incorporation and its implications for the prediction of voluntary feed intake of roughages. British Journal of Nutrition 77, 911-921.

[12] Van Soest, P. J., 1994. Nutritional ecology of the ruminant. Cornell University Press.

[13] Campos, F., Sampaio, A., Bose, M., Vieira, P., Sarmento, P., 2004. Evaluation of in vitro gas production of roughages and their mixtures using the curves subtraction method. Animal feed science and technology 116 (1): 161-172.

[14] Schofield, P., Pitt, R., Pell, A., 1994. Kinetics of fiber digestion from in vitro gas production. Journal of animal science 72 , 2980-2991.

[15] Sahoo, A., Ogra, R. K., Sood, A., Ahuja, P. S., 2010. Nutritional evaluation of bamboo cultivars in sub - Himalayan region of India by chemical composition and in vitro ruminal fermentation. Grassland science 56, 116-125.

[16] Blümmel, M., Steingass, H., Becker, K., 1994. The partitioning of in vitro fermentation products and its bearing for voluntary feed intake, Proceedings of the Society of Nutrition Physiology (Germany). http://agris.fao.org
[17] Blümmel, M., Makkar, H., Becker, K., 1997a. In vitro gas production: a technique revisited. Journal of Animal Physiology and Animal Nutrition 77, 24-34.

[18] Ouda, J., Nsahlai, I., 2009. The relevance and potential use of in vitro gas production parameters to evaluate poor quality roughage based rations for ruminants.

[19] Adejoro, F., Hassen, A., 2017. Effect of supplementing or treating Eragrostis curvula hay with urea or nitrate on its digestibility and in vitro fermentation. South African Journal of Animal Science 47, 168-177.

[20] Defar, G., Urgie, M., Melaku, S., 2017. Effect of urea treatment and concentrate mix supplementations on feed intake and digestibility of Horro sheep fed cured maize husk (Zea Mays) at Bako, Western Ethiopia. African Journal of Agricultural Research 12, 1459-1465.

[21] Makkar, H., 2004. Recent advances in the in vitro gas method for evaluation of nutritional quality of feed resources. FAO Animal Production and Health Paper, 55-88.

[22] Broderick, G., Abrams, S., Rotz, C., 1992. Ruminal in vitro degradability of protein in alfalfa harvested as standing forage or baled hay. Journal of dairy science 75, 2440-2446.

[23] Owens, F. N., Basalan, M., 2016. Ruminal fermentation, Rumenology, Springer, pp. 63-102.

[24] Maghsoud, B., Akbar, T., Hossein, J., Ali, M. G., 2008. Evaluation of some by-products using in situ and in vitro gas production techniques. American Journal of Animal and Veterinary Sciences 3, 7-12.

[25] Nsahlai, I., Fon, F., Basha, N., 2011. The effect of tannin with and without polyethylene glycol on in vitro gas production and microbial enzyme activity. South African Journal of Animal Science 41, 337-344.

[26] Khalaf, M. A., Meleigy, S. A., 2008. Reduction of free gossypol levels in cottonseed meal by microbial treatment. Int. J. Agric. Biol 10 (2): 185-190.

[27] Basha, N., Peter, S., Ahmed, M., Nsalhlai, V., 2014. Effects of season, browse species and polyethylene glycol addition on in vitro degradability of forages in the sub-humid subtropical savannah, Sounth Africa. J. Sci. Food Agr 6, 153-161.

[28] Bhatta, R., Saravanan, M., Baruah, L., Malik, P., Sampath, K., 2017. Nutrient composition, rate of fermentation and in vitro rumen methane output from tropical feedstuffs. The Journal of Agricultural Science 155, 171-183.

[29] Owen, E., Smith, T., Makkar, H., 2012. Successes and failures with animal nutrition practices and technologies in developing countries: A synthesis of an FAO e-conference. Animal Feed Science and Technology 174, 211-226.

[30] Sallam, S., Nasser, M., El-Waziry, A., Bueno, I., Abdalla, A., 2007. Use of an in vitro rumen gas production technique to evaluate some ruminant feedstuffs. J. Appl. Sci. Res 3, 34-41.

[31] Ouda, J., Nsahlai, I., 2007. Nutritive value of maize stover harvested at two stages of maturity and mixed with different types and levels of protein supplements. Journal of Applied Animal Research 32, 89-95. 